relationship between Oxbridge and the schools has set up strains elsewhere, so that an attempt to provide another special solution for the Oxbridge problem may seem a perpetuation of an existing misfortune. But this may be only half the story. Sir Desmond Lee is the principal architect of the Schools Council's proposal, now abandoned, that the sixth form curriculum for most British schoolchildren should consist of two principal courses of studies and a number of "minor" courses. Mr Morrison, on the other hand, is an advocate of a broad curriculum based on five subjects (see Nature, 215, 1329; 1967). Perhaps the Schools Council has found a way of making the principal gladiators settle their scores before tackling the more general problem of the universities as a whole.

\section{Money for Authors}

AFTER years of campaigning, it looks as if British authors may yet receive royalties for their books borrowed free from public libraries. So far there is no proposal for legislation, but authors have become more optimistic in the past few months. The problem of paying royalties to authors-the Public Lending Right, as it is called-has been bubbling away for several years now, with occasional bursts to the surface when events help or hinder the cause. Another bubble burst last week with the publication of a pamphlet, The Arts Council and Public Lending Right (6d., post free from the Arts Council).

This sets out the council's interest in the subject and outlines a scheme it proposes for a Public Lending Right (PLR). When the council set up its Literature Panel in 1966, one of the first steps was to appoint a special working party and its report was approved and adopted by the council in 1967. Because the money needed would have to come from public funds and government legislation would be necessary, the council has formally submitted the report to the Department of Education and Science. It is anybody's guess if and when the Government will promote the necessary Bill. It could possibly make the next parliamentary session, but authors fear that PLR will hardly rate among the top priorities.

Authors have long been aggrieved that there is no equivalent of the Public Performing Right to cover the lending of books from public libraries. Composers, publishers and authors receive fees for the performance of any work, musical or dramatic, in addition to the sale of the original publication. In effect, authors believe that Public Lending has become the equivalent of Public Performance. They feel that the recent development of the public libraries, which now lend about 500 million volumes a year, has taken place without anything approaching commensurate return to the producers of the books. A recent survey drew attention to the plight of some authors. Few earned anything like enough money to live on from their writing alone. It is also argued that organized lending radically affects the economics of book publishing. One library book may survive 200 issues (with one rebinding) from which the author would receive one single royalty payment and the publisher a comparable sum, from the original sale.

Earlier schemes have involved payment to authors by libraries based upon the number of times the book is issued, and the money has been obtained from small charges to borrowers. Librarians were, however, opposed to that scheme, two Government Bills were defeated and the subject was omitted from the 1964 Public Libraries Act. Librarians argued that to charge borrowers was an abandonment of "free" public libraries; that any payment to authors by libraries would involve administrative costs to the detriment of book stocks; and that the development of public libraries helped, not hindered, book producers.

In the new scheme, a system would be devised on the Danish model, using book stocks as its basis, rather than book loans as found in Sweden. It is proposed that a Library Compensation Fund Committee should be established to administer a compensation fund, which would be supplied by an annual grant paid to the committee from public funds. The size of the grant would be related to the total annual expenditure of Public Library Authorities on books. Payments to authors and publishers would depend on the stocks held in public libraries. It would be impractical for all libraries to send returns of stocks, so it is proposed that only sample libraries (three in England, for example) would send figures. These stock figures would be compared with the total of stocks held by all libraries. The fund committee would work out which books qualified under the scheme and it would then calculate the rate of compensation payable per volume.

The scheme appears to be more easy to operate than earlier suggestions, but reservations about the scheme remain. The sample of libraries, only three per year, is very small and hardly representative. Only public libraries are represented, not all libraries. Stock taking by the sample libraries will still be difficult, especially now that many libraries no longer keep such detailed records. How will the fund committee decide which authors should benefit?-British copyright books include a number not written by British nationals. Computerization of records for administering the fund might be possible now that books published since October last year have a standard book number, but this would exclude the thousands of books published previously. These points will all have to be thought out in detail by the Department of Education and Science if the scheme is to work.

\section{New Abstracts}

A NEW abstracts journal, Metals Abstracts, has begun its monthly appearance with an issue for January 1968. The journal is published jointly by the Institute of Metals, London, and the American Society for Metals, Cleveland, Ohio. It replaces the Review of Metal Literature and Metallurgical Abstracts, the respective publications of the two societies, which will now cease. Overlap between them was in fact considerable, and the new journal is a rationalization which should benefit both its producers and its users.

Metals Abstracts aims to provide a complete coverage of the world's metallurgical literature, and will in fact contain almost twice the number of abstracts that appeared in the British Metallurgical Abstracts. Industrial users in Britain may regret, however, that its price to them has also increased; the former will cost $£ 116$ ( $\$ 280$ ) a year, while the latter cost $£ 20$. For libraries the cost of Metals Abstracts will be $£ 41$ ( $\$ 100)$ and for members of the societies $£ 10$ (\$25). Monthly and annual indexes will be provided for additional fees. 
The new journal is produced and printed in Britain; the index, compiled by a computer, is produced in the United States.

\section{Physicists and Politics}

THE discussion of public issues by scientists is less rare in the United States than in Britain, where lips are usually sealed-in public, at least. But despite greater individual loquacity in the United States and the existence of several scientific journals which devote themselves to a discussion of public issues (Scientist and Citizen and The Bulletin of the Atomic Scientists, for example), the learned societies have so far kept their meetings and their journals free from controversial issues such as the war in Vietnam. But if Dr Charles Schwartz of the University of California at Berkeley has his way, the American Physical Society will soon change all this. He has proposed to the society an amendment which would allow discussion of any issue if one per cent of the membership of the society wished it. The suggestion was discussed at the APS meeting which has just finished in Chicago, and now goes to a full ballot of the membership of the society.

Predictably enough, the issue has roused passions on both sides. Dr Schwartz himself has had a brisk wrangle with the editors of Physics Today, an APS publication, about whether it should publish an account by him of the proposed amendment. His letter, eventually published along with others which give both sides of the issue, says that "there exists a whole range of issues where the technical activity of physicists gets tied up with political decision making". Unless physicists can make their opinions clear, Dr Schwartz says, they deserve to be judged by the dictum "silence implies consent". Dr Jay Orear, of Cornell University, who is chairman of the Federation of American Scientists, agrees. He thinks that scientists have a duty to protect the public from scientific hoaxes, large or small, and suggests that the establishment of an anti-missile defence system is a suitable place to start.

Dr Karl K. Darrow, however, the secretary emeritus of the APS, has other ideas. "The society has lived, thrived and done immeasurable service to physics under constitutions that limit its object to the advancement and diffusion of the knowledge of physics." Besides, opening the society to political discussions might endanger its tax-free status, he thinks. Edward Teller, from the Lawrence Radiation Laboratory, makes a more philosophical point. $\mathrm{He}$ says that pressure groups which exist in the United States have not been a beneficial addition to the constitution. Although, as he says, "it is a widely accepted thesis among physicists that they know best and should be consulted on every occasion", he thinks that physicists do best by keeping quiet, except on rare occasions when politicians make outrageous statements. Dr Frederick Scitz, president of the National Academy of Sciences, says that physicists have "countless avenues outside their profession through which they can express their views". He opposes the amendment, but sees no reason why Physics Today should not be used for some measure of social or political comment on subjects immediately related to physics.

In Britain, nobody has ever suggested that the Institute of Physics and the Physical Society (as it likes to call itself) should go in for political discussion, and Dr L. Cohen, secretary of the society, sounds enorm. ously relieved that this is so. "There's a difference in temperament, and, of course, we don't have the Vietnam war," he says, explaining the apparent indifference of British scientists. Nevertheless, there is occasionally a need for careful management-the CERN $300 \mathrm{GeV}$ machine, for example, is now as much a political as it is a scientific decision. Political discussions, he feels, would be a disruptive influence on the society, which already has to weather the tensions which result from a membership of both academic and indus. trial physicists.

\section{Wellcome Foundation}

For the first time the Wellcome Foundation-parent of three groups of companies: Wellcome or Burroughs Wellcome; Cooper, McDougall and Robertson Ltd.; and Calmic Ltd.-is making public its full annual report and accounts, containing a ten year record. The figures show that world-wide sales for the year ending August 31, 1967, reached a total of $£ 50.5$ million, an increase of just over 15 per cent on the previous year. And Sir Michael Perrin, chairman of the foundation, records profits before tax of $\mathfrak{f 6 . 3 9}$ million -an increase of 12.4 per cent. Furthermore, it seems that the effects of devaluation will on the whole be to the advantage of the foundation, because of its large overseas investments.

All profits received as dividends by the foundation are channelled into the support of medical rescarch. Expenditure by the group last year on research and development was $£ 2 \cdot 86$ million. One particular product of the group's commercial research during the year was the discovery of allopurinol, a drug which is used for the control of gout. A new scheme, mentioned in the annual report, will provide for all research and development within the group to be centrally controlled and co-ordinated - a scheme which, it is hoped, will extend business and increase the profitability of the group.

Research of a non-commercial nature is supported by the Wellcome Trust on a generous scale, and it has recently announced that a renewed grant of up to $\mathfrak{1} 36,000$ is being made to two British parasitologistsDr R. Lainson and Dr J. Shaw-to support their work in Belem, Brazil, on the epidemiology of cutaneous leishmaniasis. This is an insect-transferred discase causing extensive facial disfigurement.

The first grant of $£ 47,500$ was made in 1964 , and the decision to renew the grant was prompted by the encouraging results that have been obtained. Both Dr Lainson and Dr Shaw have worked on leishmaniasis in other parts of the world, but they chose Brazil for this particular programme because of the high incidence of the disease there and because of its particularly disfiguring effects--extensive destruction of the nose and parts of the throat. Together they have confirmed an carlier suspicion that the organism Leishmania is transferred to humans by a particular species of sandfly of the genus Phlebotomus from the primary host, which they have shown to be two species of forest rodents.

Although Dr Lainson believes that it is possible for an individual to develop immunity to the disease, very little is known about the details of the immunology and it has so far proved extremely difficult to detect antibodies in the blood of immune individuals. 